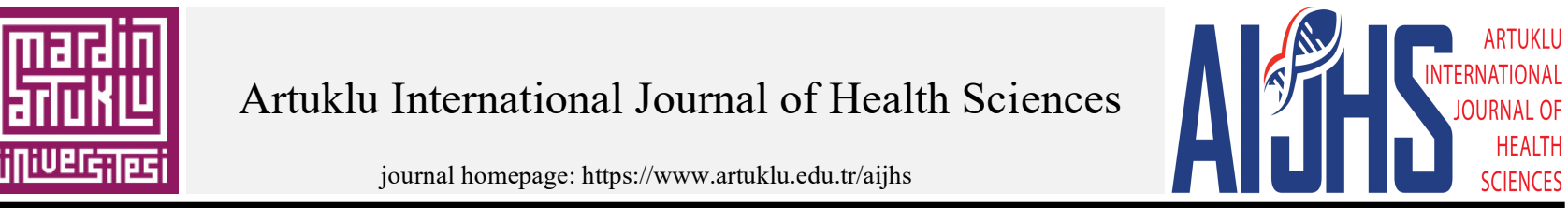

Review / Derleme

\title{
Reproductive Health Problems in Prisoner Women
}

\section{Mahkum Kadınlarda Üreme Sağlı̆̆ı Sorunları}

\author{
Beril Nisa Yaşar ${ }^{\mathrm{a}^{*}}$ \\ a Assistant Professor at Mardin Artuklu University, Faculty of Health Science, Department of Midwifery, ORCID: https://orcid.org/0000-0003-4071-1950 \\ "Corresponding Author, E-mail: yasarberil@gmail.com
}

\section{ARTICLE INFO}

Article History:

Received 06.07.2021

Received in revised form 06.08 .2021

Accepted 12.08.202

\section{Keywords:}

Women

Reproductive health

Prison

Prisoner women

\begin{abstract}
The number of female prisoners in the prison population is gradually increasing. Women prisoners are in a special category for the protection and fulfilment of their human rights. Disadvantages increase when incarceration is added to the reproductive health problems of women. It is important that prison conditions are arranged for women and that preventive health services are provided. The aim of this study is to examine reproductive health problems and provide recommendations for prisoners women in the light of the literature.
\end{abstract}

(C) 2021 Mardin Artuklu University. All rights reserved.

\section{MAKALE BİLGILERİ}

\section{Makale Geçmişi:}

Geliş Tarihi: 06.07.2021

Revizyon Tarihi: 06.08 .202

Kabul Tarihi: 12.08 .2021

Anahtar Kelimeler:

Kadin

Üreme sağlı̆

Cezaevi

Mahkum kadın

\section{ÖZET}

Cezaevleri nüfusu içinde kadın mahkumların sayısı giderek artmaktadır. Kadın mahkumlar insan haklarının korunması ve sağlanması konusunda özel kategoridedir. Kadınların üreme sağlığı sorunlarına, mahkum olma durumu da eklendiğinde dezavantajlar artmaktadır. Cezaevi koşullarının kadınlara göre düzenlenmesi ve koruyucu sağlık hizmetlerinin sunulması önemlidir. Bu makalenin amacı literatür ışığında mahkum kadınlarda üreme sağlığı sorunlarını ve önerileri incelemektir.

\section{Introduction}

The highest number of prisoners in the world is over 2.2 million in the United States (US). Seychelles is the highest rate of the prison population in the world with 799 prisoners per 100,000 people in the total population, while the US (698), St. Kitts \& Nevis (607), Turkmenistan (583), and U.S. Virgin Islands (542) followed (1).

The proportion of women in the prison population is between $2 \%$ and $9 \%$, and this rate has increased in recent years (2). In the last 40 years, the number of female prisoners has increased by $834 \%$, approximately twice as high as men (3). The number of women in prison is approximately 211,870 in the US, 107,131 in China, 48,478 in Russian Federation, 44,700 in Brazil, 41,119 in
Thailand, 17,834 in India, 12,658 in Philippines, 11,644 in Vietnam, 11,465 in Indonesia, 10,832 in Mexico, 9,807 in Myanmar and 9,708 in Turkey. The publication of the previous edition of this list in the past two years, the number of women in prison in Brazil, Indonesia, the Philippines and Turkey has increased rapidly. Since 2000 , while the male population in prison has increased by $20 \%$, it has been reported that there is an increase of more than $50 \%$ in the female population. The increase in the female population in prison cannot be explained by the increase in the population level, as the United Nations stated that the population-level increase in the world is only $21 \%$ (2).

It is known that the number of women arrested or convicted in prison has increased faster than men in recent years (4). Penal 
institutions in Turkey as of October female prisoners in Turkey constituted $3.58 \%$ of all prisoners in 2011. By the end of December 2016, 8315 of the 201,139 convicts and detainees were female and this constitute $4.1 \%$. In addition, it is known that the highest number of women $(\mathrm{n}=7953)$ in prison in Turkey in 2016 is between the ages of 21-65, covering their reproductive ages (5). Although it seems positive that the ratio of the number of female prisoners in the world to the whole prison population is low, prison rehabilitation programs and the restructuring of all prison arrangements according to male prisoners turn into a disadvantage for women (6). As women are a small minority in prisons, prison architecture, security conditions and facilities are arranged according to men, and women benefit from these practices (4). Therefore, in the context of ensuring and protecting human rights, female prisoners are considered in a special category (7). According to World Health Organization's conference named "European Union, Prison and Health", women in prison have more specific health problems than men; that female prisoners have health problems related to reproductive health; women need more of the health care provided to men; that most women in prison have a lower level of knowledge and awareness of their health condition; healthcare systems of countries have been criticized for their inability to identify and meet the health needs of women prisoners (8). Some studies found that female prisoners often experience mental health problems such as posttraumatic stress disease, depression, selfharm, and personality disorders $90 \%$ more than other women in the society $(9,10)$. The incidence of conditions such as tuberculosis, drug use, sexually transmitted diseases, HIV, hepatitis, unplanned and high risk pregnancies, sexual abuse and sex work is higher than other women (11-13) and generally reported to have risk factors such as drug use (14), violence, and unsafe sexual practices $(11,15)$. While the rate of having a smear test in female prisoners is the lowest $69 \%$ in England, it has been determined that this rate is $81.6 \%$ in the general population (16). All these risks expose female prisoners to reproductive health problems. In addition, in prisons, menstrual products such as pads may be presented as a medical item or withheld from women in order to punish them, often limiting their bathing opportunities (6). Therefore, the provision of health services in prisons is very important for women.

When the studies on the obstetric conditions of women prisoners are examined; according to the results of the studies in the US, Brazil and England, 5-10\% of female prisoners are pregnant and $90 \%$ of them give birth in prison (17); around 1400 births occurred each year (11). In addition, there is often physical and sexual violence in the stories of pregnant women convicted (18). Many health risk pregnancies resulted in childbearing and motherhood (19). Convicted mothers are usually the primary and sole caregivers of their children. When mothers are sent to prisons farther from their homes, family ties break off and serious problems arise if they have dependent children. There is no emphasis on an institutional approach and operational solutions for the solution of special problems of women arising from pregnancy or having children. It is also reported that there is a lack of standardization in abortion services and there is no full access to abortion services (20). In this case, it shows that female prisoners do not have equal rights like other pregnant women in the population when deciding whether or not to continue their pregnancy (21). In addition, when the profiles of female prisoners are examined, they are generally from mothers with children between the ages of 30 and 40 and under $18(50-80 \%)$; generally consists of low educational level, socioeconomically disadvantaged groups $(3,22)$. Women with these descriptive characteristics constitute a group with high potential to experience risky health problems. A standardized gynecological and obstetric care service is stipulated by the American Community Health Association for convicted women (23). However, the reproductive health of women in prison is often neglected (24). In gynecological examinations performed on convicted women; women are counseled in a non-professional, rude attitudes that they can understand (25).

Innovative programs implemented in prisons around the world show that success has been achieved in meeting reproductive health and other health needs. Education support groups provided by nurses in prison have reduced unplanned pregnancies with the use of contraceptives (26). Satisfied in pregnancy and birth with Lamaze educators and doula programs $(27,28)$. In Turkey, nurses are not included in the health personnel of penal institutions. According to the statute prison medical staff; doctor, dentist, pharmacist, veterinarian, dietician, health officer and animal health officer (29). Uneducated prison staff are also used to provide some health services. In addition, it was stated by prisoners that individuals who are not health staff perform operations such as injections, wound care and dressing under unhealthy and unsuitable conditions, and even critical operations such as drug distribution, which are also the duty of nurses, have to be performed by guards who have no training in healthcare (30). It has been found that the genital hygiene behaviors of women staying in detention centers are risky $(31,32)$, the 
prisoners' level of first aid knowledge is low (33), and their knowledge and practice levels of breast self-examination are insufficient (34).

\section{Conclusion and Recommendations}

The imprisonment punishment, which is binding for liberty, replaces bodily practices that break human dignity in the history of penalty and is a sanction that can be regarded as new in historical terms. While prisons used to inflict torment on the criminal in accordance with the purpose of punishment and to counter the evil she committed by committing a crime with evil, nowadays it is accepted as a place that will ensure the correction of the criminal. As the execution system of punishments binding freedom has changed, the structure, types and functions of prisons have changed. Therefore, the issue of prisons has gained importance in recent years and there have been developments regarding prisons in parallel with the changes in penal execution systems. After the emergence of the idea that prisoners also have certain rights, life models that can best meet their needs have begun to be tried. Prisons can be an important resource for health recovery. It may be an opportunity for women to regain their normal state without using drugs (detoxification and psychosocial interventions, etc.), participate in screening programs (viruses, cervical and breast cancer, etc.), exercise, learn coping methods in gaining mental health, and achieve successful social integration. It is recommended to provide preventive health services for female prisoners regarding reproductive health problems.

Competing interests: The author declared that there are no conflicts of interest.

Funding: No financial support has been received for this article.

\section{Ethical statement: Not applicable.}

\section{References}

1. World Prison Population List twelfth edition 2018. Kings College London International Centre for Prison Studies, London. Date: 15.08.2021 Available: https://www.prisonstudies.org/sites/default/files/resources/downloads/wppl_12.pdf 2. World Female Imprisonment List fourth edition 2017. Kings College London International Centre for Prison Studies, London. Date: 15.08.2021 Available: https://www.prisonstudies.org/news/world-female-imprisonment-list-fourth-edition 3. Women's Prison Association. Quick facts: Women and criminal justice. New York, NY: Institute on Women \& Criminal Justice 2020. Date: 09.08.2021 Available: https://www.wpaonline.org/issue-and-impact/
4. Cezaevi yönetimine insan haklarını gözönüne alan bir yaklaşım. International Centre for Prison Studies 2002, London. Date: 15.08.2021 Available: https://www.prisonstudies.org/sites/default/files/resources/downloads/turkish3.pdf 5. Adalet Bakanlığı Ceza ve Tevkifevleri Genel Müdürlüğü, 2016 Yılı Birim Faaliyet Raporu. Date: 04.01.2021 Available: https://cte.adalet.gov.tr/Resimler/Dokuman/20820191410332016_faliyet_raporu.p df

6. Penal Reform International. Women in prison: incarcerated in a man's world. Penal Reform Briefing 2008. Date: 15.08.2021 Available: https://cdn.penalreform.org/wp-content/uploads/2013/06/brf-03-2008-women-inprison-en.pdf

7. Human Rights and Prison, Professional Tranining Series 11 Add 1, United Nations New York and Genova 2005. Date: 15.08.2021 Available: https://www.ohchr.org/Documents/Publications/training11Add3en.pdf

8. Declaration on women's health in prison correcting gender inequity in prison health. Copenhagen \& Vienna: World Health Organization Regional Office for Europe \& United Nations Office on Drugs and Crime; 2009. Date: 15.08.2021 Available:

https://www.euro.who.int/ data/assets/pdf file/0004/76513/E92347.pdf

9. Fazel S, Danesh J. Serious mental disorder in 23000 prisoners: a systematic review of 62 surveys. Lancet. 2002; 359(9306):545-550.

10. Lafortune D. Prevalence and screening of mental disorders in short-term correctional facilities. Int J Law Psychiatry. 2010; 33(100):94-100.

11. Clarke JG, Rosengard C, Rose J, Hebert MR, Phipps MG, Stein MD. Pregnancy attitudes and contraceptive plans among women entering jail. Women Health. 2006; 43(2):111-30

12. Nijhawan AE, Salloway R, Nunn AS, Poshkus M, Clarke JG. Preventive healthcare for underserved women: Results of a prison survey. J Womens Health (Larchmt). 2010; 19(1), 17-22.

13. Watson R, Stimpson A, Hostick T. Prison health care: A review of the literature. Int J Nurs Stud. 2004; 41(2):119-128.

14. Bartlett A, Hollins S. Challenges and mental health needs of women in prison. Br J Psychiatry. 2018; 212:134-136.

15. Spaulding AC, Clarke JG, Jongco AM, Flanigan TP. Small reservoirs: jail screening for gonorrhea and chlamydia in low prevalence areas. J Correct Health Care. 2009; 15(1):28-34.

16. Plugge E, Fitzpatrick R. Factors affecting cervical screening uptake in prisoners. J Med Screen. 2004; 11(1):48-49.

17. Baldwin A, Sobolewska A, Capper T. Pregnant in prison: An integrative literature review. Women Birth. 2020; 33(1):41-50.

18. Shaw J, Downe S, Kingdon C. Systematic mixed-methods review of interventions, outcomes and experiences for imprisoned pregnant women. J Adv Nurs. 2015; 71(7):1451-63.

19. Peternelj-Taylor C. Pregnancy, childbirth, and mothering: a forensic nursing response. J Forensic Nurs. 2008; 4(2):53-4.

20. Sufrin CB, Creinin MD, Chang JC. Incarcerated women and abortion provision: a survey of correctional health providers. Perspect Sex Reprod Health. 2009; 41(1):6-11.

21. Roth R. Abortion access for imprisoned women: Marginalized medical care for a marginalized group. Womens Health Issues. 2011; 21-3S:14-15.

22. Submission to the Study of the Secretary-General of the United Nations on Violence against Women Violence against women and girls in prison. The Quaker United Nations Offices 2005. Date: 15.08.2021 Available: https:/www.un.org/womenwatch/daw//vaw/ngocontribute/Quaker\%20United\%20 Nations\%20Office, \%20Geneva.pdf

23. Correctional Health Care Standards and Accreditation, American Public Health Association, 2004. Date: 15.08.2021 Available: https://www.apha.org/policies-and- 
advocacy/public-health-policy-statements/policy-

database/2014/07/02/12/07/correctional-health-care-standards-and-accreditation

24. Braithwaite RL, Treadwell HM, Arriola KR. Health disparities and incarcerated women: a population ignored. Am J Public Health. 2005; 95(10):1679-81.

25. Magee CG, Hult JR, Turalba R, McMillan S. Preventive care for women in prison: a qualitative community health assessment of the Papanicolaou test and follow-up treatment at a California state women's prison. Am J Public Health. 2005; 95(10):1712-7.

26. Ferszt GG, Erickson-Owens DA. Development of an educational/support group for pregnant women in prison. J Forensic Nurs. 2008; 4(2):55-60.

27. Hotelling BA. Perinatal needs of pregnant, incarcerated women. J Perinat Educ. 2008; 17(2): 37-44.

28. Schroeder C, Bell J. Doula birth support for incarcerated pregnant women. Public Health Nurs. 2005; 22(1):53-58.

29. Türkiye Ceza İnfaz Kurumlarında Sağlık Hizmetleri, Sağlık Bakanlığı ve Adalet Bakanlığı arasında Ceza İnfaz Kurumlarındaki Sağlık Hizmetlerinin Düzenlenmesi Hakkında Protokol 2009. Date: 01.02.2021 Available: https://cte.adalet.gov.tr/Resimler/Dokuman/292019142507p34.pdf.

30. Eşiyok B, Yelken N, Hancı Hİ. Adli hemșirelik ve Türkiye'deki durumu. Adli Psikiyatri Dergisi. 2004; 1(3):6-10.

31. Palas P, Karaçam Z. Kadınların tutukevinde bulunmalarının genital hijyen uygulamalarına etkisi. Anadolu Hemşirelik ve Sağlık Bilimleri Dergisi. 2013; 16(1):27-35

32. Arslan Özkan İ, Kulakaç Ö. Kadın mahkumlarda genital hijyen davranışları. Anadolu Hemşirelik ve Sağlık Bilimleri Dergisi. 2011; 14(2):31-38.

33. Köksoy S, Öncü E, Şermet Ş, Sungur MA. Cezaevinde bulunan mahkûmların ilk yardım bilgi düzeyleri. Türkiye Acil Tıp Dergisi. 2012; 12(1), 20-4.

34. Harputlu D. Kadın mahkumlarda benlik saygısı ve kendi kendine meme muayenesi ilişkisi, 2005. Yüksek Lisans Tezi. Ege Üniversitesi Sağlık Bilimleri Enstitüsü. 